\title{
The Corporate Political Activity of MNCs: Taking Stock and Moving Forward
}

\author{
Jonas Puck ${ }^{1}$ - Thomas Lawton ${ }^{2,3}$ - Alexander Mohr ${ }^{4}$ \\ Published online: 8 October 2018 \\ ๑) Springer-Verlag GmbH Germany, part of Springer Nature 2018
}

\section{Introduction}

For the past 50 years, business and management and political science and international relations scholars alike have studied multinational corporations (MNCs) ties with political and regulatory actors and agents, particularly governments, political institutions, and regulators. We refer to such efforts by the firm to influence or manage political entities as corporate political activity (CPA) (Hillman and Hitt 1999; Hillman et al. 2004; Lawton et al. 2013a, b). Both academics and practitioners frequently highlight the relevance of CPA in and across international markets and call for further integration of the non-market perspective into international business and management research (Lawton et al. 2014).

MNCs engage in such activities for at least three, partially overlapping reasons. First, and specifically in the international business environment, companies encounter a wide variety of regulations and public policies enacted by regional and national governments and by international or supranational treaties and organizations such as the North American Free Trade Agreement or the European Union. This creates substantial complexity and costs for firms. Consequently, firms try to better understand and engage with this environment through CPA (e.g., Lawton et al. 2013a, b). Second, the political environment in each market can create significant threats for firms and negatively influence MNCs strategic options and performance, e.g., through regulatory or legal measures (De Villa et al. 2015). Firms often respond to such political and regulatory pressures by using different types of corporate political activities, including engaged and non-engaged approaches (e.g., De Villa et al. 2018; Nell et al. 2015; Puck et al. 2013). Lastly, political environments can also create opportunities for firms. MNCs, try to create strategic opportunities, such as

Jonas Puck

jonas.puck@wu.ac.at

1 WU Vienna, Institute for International Business, Vienna, Austria

2 Cork University Business School, Cork, Ireland

3 Surrey Business School, University of Surrey, Guildford, Surrey, UK

4 WU Vienna, Institute for Export Management, Vienna, Austria 
favorable investment conditions, preferential treatments, or similar, using CPA in a proactive way (Heidenreich et al. 2015; Shirodkar and Mohr 2015a, b).

Existing research has created a wealth of insights into the CPA of MNCs. However, assessing CPA research in the context of internationalization and the MNC, we argue that our knowledge of many dimensions of MNC non-market, political strategies is still rather limited, specifically when compared to research on the market side of strategy. With this focused issue, we therefore intend, both theoretically and empirically, to venture further into this research realm.

\section{Aim and Content of this Focused Issue}

In our call for papers for this focused issue, we highlighted the need for research in the following four areas.

\subsection{Drivers of MNC Corporate Political Activity (CPA)}

Identifying the factors that lead firms to engage in CPA, or factors that affects firms' choice of particular types of CPA, is the subject of the majority of prior studies into the CPA of MNCs. Recent research has discussed a large number of such drivers at the firm-level (De Villa et al. 2018; Funk and Hirschman 2017; Lawton et al. 2013a, b; Shirodkar and Mohr 2015a, b), industry-level (Lawton et al. 2013a, b; Mbalyohere and Lawton 2018; Mbalyohere et al. 2017; Schuler 1996) or country/institutional-level (Banerjee and Venaik 2018; Choi et al. 2014; Holtbruegge et al. 2007; Sojli and Tham 2017; Zhang et al. 2016). Given the nature of MNCs, however, we perceive a need for more research specifically into the idiosyncrasies of firm contexts and into how these contexts interact with firm-level drivers of firms' choice of political strategy in different markets. Recent research in this vein has, for example, investigated the relative importance of non-market capabilities versus supranational institutional safeguards as a means to mitigate against risks in overseas markets (Albino-Pimentel et al. 2018).

In this focused issue, Liedong and Frynas (2018), Voinea and van Kranenburg (2018) and White et al. (2018) draw on institutional theory to explore how specific characteristics of institutional contexts shape firms' political activities and strategy.

\subsection{Management and Organization of CPA}

Despite some recent advances, we still know relatively little about the management and organization of CPA within the MNC Doh et al. (2014). For example, discuss how MNCs can benefit from a chief external officer, ensuring ownership of nonmarket issues is explicitly integrated into the corporation's strategic decision-making and top management team profile. There is also ample evidence that organizing CPA across borders represents a substantial challenge for the MNC (Blumentritt and Nigh 2002; Kobrin 2015). Overall, however, our knowledge on the challenges of organizing CPA across borders remains fragmented. Therefore, we called for submissions 
addressing CPA management, organization, and structure within MNCs as promising avenues for theory development in the field.

In this focused issue, the paper by Elsahn and Benson-Rea (2018) takes a more micro-level perspective and explores the interplay between MNC management's attitude towards external stakeholders and the implementation of different political strategies.

\subsection{Outcomes of CPA in MNCs}

We also argue that research on the effectiveness of non-market strategy across borders remains scarce (Doh et al. 2012, 2015; Dorobantu et al. 2017). Research has identified and analyzed the performance and other outcomes of political strategies. For example, Nell et al. (2015) found a positive and significant relationship between the use of the three types of political strategy suggested by Hillman and Hitt (1999) and the goal achievement perceived by subsidiary managers (Nell et al. 2015). Similarly, Heidenreich et al. (2014) investigated the effects of firms' use of Hillman and Hitt's (1999) information and financial incentives strategy (Hillman and Hitt 1999) on firms' development of a stakeholder network and their performance. Furthermore, Jia (2014) analyzed to what extent public and private political actions are substituting or complementing each other. Because of the often inconsistent and even conflicting findings as to the effects of different types of CPA, extant research has also explored the contingent nature of the performance effects and other outcomes of political strategies. For example, Luo and Zhao (2013) suggested two firmlevel variables-subsidiary reputation and length of operations in the host country-to moderate the positive link between a relational political strategy used at the subsidiary level and the firm's performance in the host country. Mohr et al. (2016) investigated how the effect of partnering with state-controlled actors on the survival of international joint ventures in China varies with the type of state-controlled actor, the foreign firm's host-country experience as well as the age of the joint venture. Also focusing on firms' CPA in China, Yan and Chang (2018) examined the (interdependent) effects of firms' having political connections to different government institutions.

We see more space for theoretical and empirical contributions that theorize about, and empirically explore, the contingent nature of the effects of CPA. Specifically, while there has been research on the role of institutional contingencies in the domestic context (Kozhikode and Li 2012), there is a need to clarify the role how differences in the institutional characteristics in firms' home and host country or countries, as well as the differences between such characteristics, may affect the consequences of firms' use of different types of CPA (Seong-Jin et al. 2015).

In our focused issue, Banerjee and Venaik (2018) draw on institutional theory to investigate the effects that different political strategies have on firm legitimacy, whereas Arreola and Bandeira-de-Mello (2018) investigate how minority state ownership affects the subsequent internationalization of emerging market multinationals. 


\subsection{Integration of CPA and CSR in MNCs}

Despite the clear inter-relationship between CPA and CSR, there has been limited research on when and how MNCs integrate different types of non-market strategies across global markets. Although scholars have started addressing this interdependence in firms' non-market strategy in a national context (Den Hond et al. 2014; Mellahi et al. 2016), our understanding of this interdependence in international firms remains limited. Addressing such questions would help to develop a better understanding of the overlap between, and integration of, the two key pillars of nonmarket strategy in an international setting. Similarly, there remains a relative lack of research clarifying the link between market- and non-market strategy (Funk and Hirschman 2017). Although some of the papers we include in this focused issue touch upon the integration of CPA and other elements of non-market strategy, we did not receive any submissions specifically aimed at addressing this integration. It thus remains one of the areas in need of further research.

\subsection{Papers in this Focused Issue}

In line with the call for papers, the papers included in this focused issue can be grouped according to their main contribution into: (a) Drivers of MNC CPA; (b) Management and organization of CPA; and (c) Outcomes of CPA in MNCs. In the following, we briefly outline how the individual papers contribute to each of these topics.

We have included three papers that study different drivers of MNCs' CPA. First, Liedong and Frynas (2018) investigate the drivers of CPA with their paper Investment climate constraints as determinants of political tie intensity in emerging countries: Evidence from foreign firms in Ghana. The authors draw on institutional theory to deepen our understanding of how different types of investment climate constraints affect MNC CPA strategies in emerging countries. More precisely, the authors categorize investment climate constraints into administrative factors, such as corruption, and control constraints, such as profit repatriation restrictions, and argue that both have a positive effect on the intensity of local political ties. While the extant literature is rich in studies on each of these constraints in isolation, we lack understanding about the relative influence of these two constraints. In addition, the authors hypothesize that the existence of local public affairs functions moderates this relationship. They test their hypotheses empirically using survey data from 80 respondents of foreign subsidiaries operating in Ghana and find support for some of their hypotheses. With this paper, the authors contribute to CPA and international business literature in three ways. First, they illustrate how different constraints affect political tie intensity, thus adding to our knowledge of CPA antecedents. Second, the paper explores the role of the public affairs function, a research question which has so far been largely neglected. Last, using data collected in Africa, the study adds to our understanding of a geographically often overlooked region.

Second, in their paper Feeling the squeeze: Nonmarket institutional pressures and firm nonmarket strategies, Voinea and van Kranenburg (2018) add to our 
understanding of the drivers of CPA by delineating how the pressures from different non-market institutions translate into specific MNC political strategies. More precisely, the authors integrate new institutional economics and the neo-institutional perspective to conclude that the strategies used by MNCs to manage such institutional pressures depend on the power held by the respective institution. Furthermore, the authors explore factors determining the pressure from each non-market institution. By using the data of respondents from a survey of foreign MNCs operating in the Netherlands, and by applying structural equation modelling and partial least squares path modelling, the authors provide evidence on factors determining institutional pressures. The authors show that MNCs manage pressures from political institutions, interest groups, and the media through relational strategies, whilst they use transactional strategies to manage pressures from regulatory agencies and standards agencies. The authors contribute to research on international CPA in two ways. First, they enable us to better understand the relationship between various types of nonmarket institutional pressures, their drivers, and MNCs' choices between different CPA strategies, a topic which has so far been largely overlooked. Second, they contribute to our understanding of the political behavior of MNCs in a non-US setting.

Third, White et al. (2018) investigate the drivers of CPA in MNCs by exploring how MNCs use political ties in response to perceived regulator uncertainty. In their study Regulator vulnerabilities to political pressures and political tie intensity: The moderating effects of regulatory and political distance, the authors draw on the institution-based view and neo-institutional theory to deepen our understanding of how MNCs use their connections to host country governments to safeguard their foreign operations against volatile policy processes and unpredictable individual policymakers. More precisely, the authors hypothesize that managerial perceptions of regulator vulnerability to political pressures contributes to the intensification of political ties, as firms aim to use these political ties to hedge their business against policy uncertainty. Furthermore, they argue that MNCs from politically or regulatory different countries are less capable of pursuing such strategies. The authors provide empirical evidence for their hypotheses by using survey data from a sample of 181 wholly owned foreign subsidiaries operating in the Philippines. By doing so, they contribute to international CPA literature by exploring the previously neglected relationship between policy uncertainty, political and regulatory distance, and intensity of political ties to local government agents. Furthermore, the authors deepen our understanding of a relatively unexplored geography, the Philippines.

Focusing on the management and organization of CPA in MNCs, Elsahn and Benson-Rea (2018) paper, Political schemas and corporate political activities during foreign market entry: A micro-process perspective, adopts a micro-process perspective to investigate the role of MNC management's attitude towards external stakeholders that shapes their preference for certain political strategies. The paper contributes to CPA theory by investigating political strategies in the context of foreign market entries through a micro-process perspective, which has so far remained largely neglected by scholarly work. The authors do so by conducting an inductive multiple case study with semi-structured interviews involving 16 respondents from six New Zealand MNCs. Following this methodology, they identify two political schemas, systematic and episodic, describing the MNC management's attitude 
towards how to approach external political stakeholders. They proceed and propose that each schema leads to different preferences for political strategies, a relationship which is further moderated by factors at the managerial, firm, industry and country level. Hence, the authors contribute to the debate on CPA by explaining how processes underlying MNCs' CPA strategies during market entries function at the micro level. In doing so, they complement current CPA research, which has largely remained at a macro perspective, such as external institutions or internal organizational structures, and improve our understanding of processes underlying the CPA of international firms.

Our focused issue includes two papers that have analyzed the outcomes of MNCs' CPA. First, addressing effects and effectiveness of CPA strategies in their paper The effect of corporate political activity on MNC subsidiary legitimacy: An institutional perspective, Banerjee and Venaik (2018) draw on institutional theory to deepen our understanding of how MNC subsidiaries can use CPA strategies to build legitimacy in foreign host markets and overcome their liability of foreignness. The authors identify five corporate political strategies using mimetic isomorphism, information, financial, constituency building and relational approaches, respectively, and they hypothesize that each of these strategies has a positive effect on legitimacy. The authors go on and test these five hypotheses through a self-administered questionnaire survey, using a sample of 214 top executives and senior managers from foreign subsidiaries operating in Australia. Using regression analysis to test the data gathered through this survey, the authors find empirical support for most of their hypothesized relationships between different CPA strategies and legitimacy. From a global perspective, the authors contribute to the ongoing discussion on how foreign firms can manage their political dependencies in host countries. More specifically, this paper offers three contributions to international business and CPA literatures. First, the authors illustrate how the political strategies of foreign subsidiaries can be used to manage their external stakeholders to gain legitimacy. Second, the study provides insights on complementary effects between different CPA strategies. Third, the authors add to the debate on how MNCs can balance the need for mimetic isomorphism against the need for innovativeness.

The second paper addressing effects of CPA strategies, is The differential effects of minority state ownership types on the internationalization of emerging market multinationals from democratic states, by Arreola and Bandeira-de-Mello (2018). The authors draw on the political survival literature and add to the theory on political ties by arguing that different types of minority state equity have different effects on the internationalization of firms. The authors reason that this is due to differences in governance profiles between these two ownership types. They proceed and provide empirical support for their hypotheses by combining a quantitative analysis of a sample of Brazilian multinationals in the form of instrumental and fixedeffects regressions with a qualitative case study analysis. Previous research on political research has predominantly used China as an empirical setting, hence limiting external validity due to differences in decision-making mechanisms between democratic and authoritarian systems. By using a sample from Brazil, a democratic country, the paper aims to close this methodological gap. In addition, the paper makes three distinct theory contributions. First, the authors provide empirical evidence on 
the effects of state ownership on the internationalization of domestic multinationals from democratic countries. Second, the authors show under which conditions minority state ownership ties have positive and negative effects on the internationalization of emerging market multinationals. Finally, the authors provide new insights on the mechanisms underlying this relationship.

\section{Moving Forward: What's Next in MNC CPA Research}

With this focused issue we intended to contribute to international CPA research by exploring four questions: First, what are the drivers of CPA in multinational corporations? Second, how do MNCs manage and organize CPA? Third, what, if any, are the effects and outcomes of MNCs' use of CPA? Fourth, how do MNCs integrate their CPA with other (non-market and market) strategies? We have already suggested how this focused issue contributes to answering the first three of these questions. However, we lack a profound understanding of how CPA can be integrated with other, often conflicting, strategic objectives and processes. Recent research emphasizes the strategic importance of aligning CPA and CSR within non-market strategy and the risks associated with contradictory or conflictual market and nonmarket strategies (Den Hond et al. 2014; Lawton et al. 2014; Mellahi et al. 2016). Further research is required to explore internal organizational alignment processes, alignment structural configurations, coping strategies, and the effects of strategic misalignment.

Although the absence of research on the alignment or integration of CPA with MNC strategy is particularly striking, there are also unanswered question regarding our first three questions, i.e., the drivers, management, and outcomes of MNC CPA. We call on scholars in international business and adjacent fields to continue work in these areas. On the question of the drivers of CPA in MNCs, we see particular potential in further research on the nature and development of political capabilities in MNCs and how these capabilities shape the CPA of MNCs. While some of the papers in this focused issue contribute to this endeavor, more work is needed. In particular, the research stream connecting MNC behavior in foreign markets to home country characteristics (see, for instance, Cuervo-Cazurra 2006; Cuervo-Cazurra and Genc 2008; De Villa et al. 2018; García-Canal and Guillén 2008; Holburn and Zelner 2010; Luo and Wang 2012; Meyer et al. 2018; Stoian and Mohr 2016) suggests that this could be a fruitful avenue for future research. For instance, it may be worth exploring how the political resources and capabilities which an MNC has built in its home country, affect the nature and focus of its international strategies.

More work is also needed to enhance our understanding of the management and organization of CPA in MNEs. Many practitioners remain uncertain as to how CPA can be optimally configured and managed to add value, particularly within complex and diversified multinationals. Much in-depth and comparative research remains to be done on the internal operational processes and management structures of CPA within MNCs, and particularly between headquarters and overseas subsidiaries. We also need to better understand the nature and optimization of internal versus external CPA. When and why do MNCs outsource CPA 
to management consultancies or law firms? What are the limitations of an externalized approach to CPA? What role can third parties such as trade associations play in the design and delivery of CPA for MNCs, both at home and abroad? Further, we see potential in studying how CPA relates to internal micro-politics and conflict management within MNCs (Dörrenbächer and Geppert 2006, 2009). We also suggest building on and extending work on the micro-foundations of strategy (Barney and Felin 2013; Foss 2011; Foss and Pedersen 2016) to analyze the micro-foundations of CPA. This seems particularly promising given that firms' political ties are tied to particular individuals.

With regard to the outcomes and effectiveness of CPA, we suggest that scholars broaden their view on what constitutes relevant effectiveness criteria and outcome measures to be studied. In particular, to reflect on the longer-term outputs and outcomes that CPA may foster, which can be difficult to conclusively capture in most studies. This can be even more so for MNCs engaging in host countries and deploying CPA to gradually build legitimacy, gain access, and overcome the liability of foreignness. Moreover, insights from practice would suggest that the results of CPA are often more intangible than tangible, and therefore difficult to capture and measure. In particular, the legitimacy, influence, and power that CPA garners for MNCs. There can of course be a dark side to CPA in these cases, where corrupt practices and illegal behavior are facilitated by the connections and authority that CPA delivers. More work is needed in this area, particularly exploring the long term and intangible outcomes and effectiveness of CPA for MNCs, and also the connectivity between, and organizational and institutional responses to, irresponsible CPA and MNC corrupt practices. There is growing evidence and consensus that more developed and robust institutions can reduce corruption, particularly in emerging markets (Mbalyohere et al. 2017; Mbalyohere and Lawton 2018), and MNCs are encouraged to play a role in transmitting clear and consistent CPA practices to their overseas subsidiaries (Rajwani and Liedong 2015). It is argued that there is room for multinationals from home countries where CPA is regulated, to push for similar laws in emerging economies, with the goal of resolving any anarchical or improper political engagement. This suggests that MNEs act as institutional entrepreneurs by transferring rules to develop fragile institutions and advocating best practices, and in this way contribute to global governance (Rajwani and Liedong 2015). Interdisciplinary approaches may be helpful to further research in these areas, bringing useful ethical insights and practices from political science, sociology or philosophy (Scherer and Palazzo 2007).

Although there are innumerable challenges to data collection and to the reliability and robustness of findings in emerging economies, more work is needed on multinational CPA process and practice in much of the world. Many seminal CPA studies rely on data from the United States, and whilst there is a growing body of research drawing on evidence from China in particular, a more global approach is needed. The papers in this focused issue go some way to addressing this deficit.

In sum, the papers in this focused issue provide relevant new insights into the political activity of MNCs. They specifically add to our theoretical understanding of the drivers, organization, and consequences of such activities. At the same time, we have discussed a number of relevant gaps in the literature in the last chapter of this 
paper. We are confident that addressing those gaps will help to develop our understanding of the topic as well as its impact on firms and societies.

\section{References}

Albino-Pimentel, J., Dussauge, P., \& Shaver, J. M. (2018). Firm non-market capabilities and the effect of supranational institutional safeguards on the location choice of international investments. Strategic Management Journal. https://doi.org/10.1002/smj.2927.

Arreola, F., \& Bandeira-de-Mello, R. (2018). The differential effects of minority state ownership types on the internationalization of emerging market multinationals from democratic states. Management International Review. https://doi.org/10.1007/s11575-018-0352-4.

Banerjee, S., \& Venaik, S. (2018). The effect of corporate political activity on MNC subsidiary legitimacy: An institutional perspective. Management International Review. https://doi.org/10.1007/ s11575-017-0324-0.

Barney, J. A. Y., \& Felin, T. (2013). What are microfoundations? Academy of Management Perspectives, 27(2), 138-155.

Blumentritt, T. P., \& Nigh, D. (2002). The integration of subsidiary political activities in multinational corporations. Journal of International Business Studies, 33(1), 57-77.

Choi, S. J., Jia, N., \& Lu, J. (2014). The structure of political institutions and effectiveness of corporate political lobbying. Organization Science, 26(1), 158-179.

Cuervo-Cazurra, A. (2006). Who cares about corruption? Journal of International Business Studies, $37(6), 807-822$.

Cuervo-Cazurra, A., \& Genc, M. (2008). Transforming disadvantages into advantages: Developingcountry MNEs in the least developed countries. Journal of International Business Studies, 39(6), 957-979.

De Villa, M. A., Rajwani, T., \& Lawton, T. (2015). Market entry modes in a multipolar world: Untangling the moderating effect of the political environment. International Business Review, 24(3), 419-429.

De Villa, M. A., Rajwani, T., Lawton, T. C., \& Mellahi, K. (2018). To engage or not to engage with host governments: Corporate political activity and host country political risk. Global Strategy Journal. https://doi.org/10.1002/gsj.1205.

Den Hond, F., Rehbein, K. A., de Bakker, F. G., \& Lankveld, H. K. V. (2014). Playing on two chessboards: Reputation effects between corporate social responsibility (CSR) and corporate political activity (CPA). Journal of Management Studies, 51(5), 790-813.

Doh, J. P., Lawton, T. C., \& Rajwani, T. (2012). Advancing nonmarket strategy research: Institutional perspectives in a changing world. Academy of Management Perspectives, 26(3), 22-39.

Doh, J. P., Lawton, T. C., Rajwani, T., \& Paroutis, S. (2014). Why your company may need a chief external officer. Organizational Dynamics, 43(2), 96-104.

Doh, J., McGuire, S., \& Ozaki, T. (2015). The Journal of World Business special issue: Global governance and international nonmarket strategies: Introduction to the special issue. Journal of World Business, 50(2), 256-261.

Dorobantu, S., Kaul, A., \& Zelner, B. (2017). Nonmarket strategy research through the lens of new institutional economics: An integrative review and future directions. Strategic Management Journal, 38(1), 114-140.

Dörrenbächer, C., \& Geppert, M. (2006). Micro-politics and conflicts in multinational corporations: Current debates, re-framing, and contributions of this special issue. Journal of International Management, 12(3), 251-265.

Dörrenbächer, C., \& Geppert, M. (2009). A micro-political perspective on subsidiary initiative-taking: Evidence from German-owned subsidiaries in France. European Management Journal, 27(2), $100-112$.

Elsahn, Z., \& Benson-Rea, M. (2018). Political schemas and corporate political activities during foreign market entry: A micro-process perspective. Management International Review. https://doi. org/10.1007/s11575-018-0350-6.

Foss, N. J. (2011). Why micro-foundations for resource-based theory are needed and what they may look like. Journal of Management, 37(5), 1413-1428. 
Foss, N. J., \& Pedersen, T. (2016). Microfoundations in strategy research. Strategic Management Journal, 37(13), E22-E34.

Funk, R. J., \& Hirschman, D. (2017). Beyond nonmarket strategy. Market actions as corporate political activity. Academy of Management Review, 42(1), 32-52.

García-Canal, E., \& Guillén, M. F. (2008). Risk and the strategy of foreign location choice in regulated industries. Strategic Management Journal, 29(10), 1097-1115.

Heidenreich, S., Mohr, A., \& Puck, J. F. (2015). Political strategies, entrepreneurial overconfidence and foreign direct investment in developing countries. Journal of World Business, 50(40), 793-803.

Heidenreich, S., Puck, J. F., Filatotchev, I., et al. (2014). Complementarity versus substitution among political strategies. In T. Pedersen (Ed.), Advances in International Management: Orchestration of the Global Network Organization (Vol. 27, pp. 235-262). Bingley: Emerald Group Publishing Limited.

Hillman, A. J., \& Hitt, M. A. (1999). Corporate political strategy formulation: A model of approach, participation, and strategy decisions. Academy of Management Review, 24(4), 825-842.

Hillman, A. J., Keim, G. D., \& Schuler, D. (2004). Corporate political activity: A review and research agenda. Journal of Management, 30(6), 837-857.

Holburn, G. L. F., \& Zelner, B. A. (2010). Political capabilties, policy risk, and international investment strategy: Evidence from the global electric power generation industry. Strategic Management Journal, 31(12), 1290-1315.

Holtbruegge, D., Berg, N., \& Puck, J. F. (2007). To bribe or to convince? Political stakeholders and political activities in German multinational corporations. International Business Review, 16(1), 47-67.

Jia, N. (2014). Are collective political actions and private political actions substitutes or complements? Empirical evidence from China's private sector. Strategic Management Journal, 35(2), 292-315.

Kobrin, S. J. (2015). Is a global nonmarket strategy possible? Economic integration in a multipolar world order. Journal of World Business, 50(2), 262-272.

Kozhikode, R. K., \& Li, J. (2012). Political pluralism, public policies, and organizational choices: Banking branch expansion in India, 1948-2003. Academy of Management Journal, 55(2), 339-359.

Lawton, T. C., Doh, J. P., \& Rajwani, T. (2014). Aligning for Advantage: Competitive Strategies for the Political and Social Arenas. Oxford: Oxford University Press.

Lawton, T., McGuire, S., \& Rajwani, T. (2013a). Corporate political activity: A literature review and research agenda. International Journal of Management Reviews, 15(1), 86-105.

Lawton, T., Rajwani, T., \& Doh, J. (2013b). The antecedents of political capabilities: A study of ownership, cross-border activity and organization at legacy airlines in a deregulatory context. International Business Review, 22(1), 228-242.

Liedong, T. A., \& Frynas, J. G. (2018). Investment climate constraints as determinants of political tie intensity in emerging countries: Evidence from foreign firms in Ghana. Management International Review. https://doi.org/10.1007/s11575-018-0354-2.

Luo, Y., \& Wang, S. L. (2012). Foreign direct investment strategies by developing country multinationals: A diagnostic model for home country effects. Global Strategy Journal, 2(3), 244-261.

Luo, Y., \& Zhao, H. (2013). Doing business in a transitional society: Economic environment and relational political strategy for multinationals. Business and Society, 52(3), 515-549.

Mbalyohere, C., \& Lawton, T. C. (2018). Engaging stakeholders through corporate political activity: Insights from MNE nonmarket strategy in an emerging African market. Journal of International Management. https://doi.org/10.1016/j.intman.2018.04.006.

Mbalyohere, C., Lawton, T., Boojihawon, R., \& Viney, H. (2017). Corporate political activity and location-based advantage: MNE responses to institutional transformation in Uganda's electricity industry. Journal of World Business, 52(6), 743-759.

Mellahi, K., Frynas, J. G., Sun, P., \& Siegel, D. (2016). A review of the nonmarket strategy literature: Toward a multi-theoretical integration. Journal of Management, 42(1), 143-173.

Meyer, K. E., Ding, Y., Li, J., \& Zhang, H. (2018). Overcoming distrust: How state-owned enterprises adapt their foreign entries to institutional pressures abroad. In A. Cuervo-Cazurra (Ed.), StateOwned Multinationals (pp. 211-251). Basingstoke: Palgrave Macmillan.

Mohr, A., Wang, C., \& Fastoso, F. (2016). The contingent effect of state participation on the dissolution of international joint ventures: A resource dependence approach. Journal of International Business Studies, 47(4), 408-426.

Nell, P. C., Puck, J. F., \& Heidenreich, S. (2015). Strictly limited choice or agency? Institutional duality, legitimacy, and subsidiaries' political strategies. Journal of World Business, 50(2), 302-311. 
Puck, J. F., Rogers, H., \& Mohr, A. T. (2013). Flying under the radar: Foreign firm visibility and the efficacy of political strategies in emerging economies. International Business Review, 22(6), 1021-1033.

Rajwani, T., \& Liedong, T. A. (2015). Political activity and firm performance within nonmarket research: A review and international comparative assessment. Journal of World Business, 50(2), 273-283.

Scherer, A. G., \& Palazzo, G. (2007). Toward a political conception of corporate responsibility: Business and society seen from a Habermasian perspective. Academy of Management Review, 32(4), 1096-1120.

Schuler, D. A. (1996). Corporate political strategy and foreign competition: The case of the steel industry. Academy of Management Journal, 39(3), 720-737.

Seong-Jin, C., Nan, J., \& Jiangyong, L. (2015). The structure of political institutions and effectiveness of corporate political lobbying. Organization Science, 26(1), 158-179.

Shirodkar, V., \& Mohr, A. (2015a). Resource tangibility and foreign firms' corporate political strategies in emerging economies: Evidence from India. Management International Review, 55(6), 801-825.

Shirodkar, V., \& Mohr, A. T. (2015b). Explaining foreign firms' approaches to corporate political activity in emerging economies: The effects of resource criticality, product diversification, inter-subsidiary integration, and business ties. International Business Review, 24(4), 567-579.

Sojli, E., \& Tham, W. (2017). Foreign political connections. Journal of International Business Studies, 48(2), 244-266.

Stoian, C., \& Mohr, A. (2016). Outward foreign direct investment from emerging economies: Escaping home country regulative voids. International Business Review, 25(5), 1124-1135.

Voinea, C. L., \& van Kranenburg, H. (2018). Feeling the squeeze: Nonmarket institutional pressures and firm nonmarket strategies. Management International Review. https://doi.org/10.1007/s1157 5-018-0355-1.

White, G. O., Boddewyn, J. J., Rajwani, T., \& Hemphill, T. (2018). Regulator vulnerabilities to political pressures and political tie intensity: The moderating effects of regulatory and political distance. Management International Review. https://doi.org/10.1007/s11575-018-0351-5.

Yan, J. Z., \& Chang, S. J. (2018). The contingent effects of political strategies on firm performance: A political network perspective. Strategic Management Journal, 39(8), 2152-2177.

Zhang, Y., Zhao, W., \& Ge, J. (2016). Institutional duality and political strategies of foreign-invested firms in an emerging economy. Journal of World Business, 51(3), 451-462. 